\title{
Improvement of yield and yield stability in safflower using multivariate, parametric and non-parametric methods under different irrigation treat- ments and planting date
}

\author{
Pooran GOLKAR ${ }^{1,2,3}$, Nasrin RAHMATABADI ${ }^{4}$, Seyyed Ali Mohammad MIRMOHAMMADY \\ MAIBODY $^{4}$
}

Received September 01, 2019; accepted March 31, 2020.

Delo je prispelo 01. septembra 2020, sprejeto 31. marca 2020

\begin{abstract}
Improvement of yield and yield stability in safflower using multivariate, parametric and non-parametric methods under different irrigation treatments and planting date

Abstract: Development of superior genotypes with high adaptability to different environments is considered as one of the most important goals in safflower breeding programs. In this study, ten parametric and six non-parametric measures along with the additive main effects and the relevant multiplicative interaction (AMMI) model were used to evaluate genotype by environment interaction (GE) in 15 safflower genotypes across 12 test environments ) combination of year, planting date and moisture conditions) during growing seasons in 2016 and 2017. AMMI analysis revealed significant differences among the genotypes and their GE interactions. The different stability statistics were substantiated by rank correlation coefficient. Rank-correlation coefficients revealed positive and significant correlations between mean seed yield and superiority index $\left(\mathrm{r}=0.99^{* *}\right)$, and significant and negative correlation with bi, $\mathrm{R}^{2}, \mathrm{D}_{\mathrm{ij}}$ and non- parametric measures $\left(\mathrm{NPi}^{(2)}, \mathrm{NPi}^{(3)}\right.$ and $\left.\mathrm{NPi}^{(4)}\right)$. Based on most stability parameters, the Mex.295 genotype $\left(G_{10}\right)$ was found to be the most stable for seed yield. IL.111 genotype $\left(G_{9}\right)$ recorded the highest mean yielding genotype regarded as the most favorable safflower genotype. In conclusion, both stability and seed yield should be simultaneously considered to exploit useful effects of $\mathrm{G} \times \mathrm{E}$ interactions in safflower breeding programs.
\end{abstract}

Key words: safflower; parametric and non-parametric measures; yield, rank correlation
Izboljšanje pridelka žafranike in njegove stabilnosti z multivariatnimi parametričnimi in neparametričnimi metodami pri različnem namakanju in datumih setve

Izvleček: Razvoj superiornih genotipov z veliko prilagodljivostjo različnim okoljem je eden izmed najvažnejših ciljev v žlahniteljskih programih žafranike. V raziskavi je bilo uporabljenih deset parametričnih in šest neparametričnih meril vključno $\mathrm{z}$ glavnimi aditivnimi učinki in modelom pomembnih multiplikativnih interakcij (AMMI) za ovrednotenje interakcije genotipa z okoljem (GE) pri 15 genotipih žafranike, preiskušenih v 12 okoljih )kombinacija leta poskusa, datuma setve in vlažnostnih razmer) v rastnih sezonah 2016 in 2017. AMMI analiza je odkrila značilne razlike $\mathrm{v}$ interakcijah genotipov z okoljem. Različne statistične metode za ovrednotenje različnih vidikov stabilnosti pridelka so bile uspešno nadomeščene s koeficientom gradualne korelacije. Ti koeficienti so odkrili pozitivne in značilne korelacije med poprečnim pridelkom semena in indeksom superiornosti $\left(r=0.99^{* *}\right)$, in značilne negativne korelacije $\mathrm{z}$ bi, $\mathrm{R}^{2}, \mathrm{D}_{\mathrm{ij}}$ in neparametričnimi merili $\left(\mathrm{NPi}^{(2)}, \mathrm{NPi}^{(3)}\right.$ in $\left.\mathrm{NPi}^{(4)}\right)$. Na osnovi večine parametrov stabilnosti je bil genotip Mex.295, $\left(\mathrm{G}_{10}\right)$ prepoznan kot najbolj stabilen za pridelek semena. Genotip IL.111 $\left(\mathrm{G}_{9}\right)$ je bil prepoznan kot najboljši genotip žafranike $\mathrm{z}$ največjim poprečnim pridelkom. Zaključimo lahko, da je v žlahtniteljskih programih Žafranike potrebno hkrati upoštevati velikost in stabilnost pridelka, če hočemo izkoristiti koristne interakcije okolja in genotipa $(\mathrm{G} \times \mathrm{E})$.

Ključne besede: žafranika; parametrična in neparametrična merila; pridelek; korelacija rangov

Isfahan University of Technology, Department of Natural Resources, Iran

2 Isfahan University of Technology, Research Institute for Biotechnology and Bioengineering, Iran

3 Corresponding author, e-mail: poorangolkar@gmail.com, golkar@iut.ac.ir

4 Isfahan University of Technology, Department of Agronomy and Plant Breeding, College of Agriculture, Iran 


\section{INTRODUCTION}

Safflower (Carthamus tinctorius L.) is mainly grown in dryland conditions of the world as an oilseed crop with diverse genetic backgrounds and the pharmaceutical industry uses (Kumar et al., 2016). Safflower have tremendous potential for cosmetic industry and organic food and other usages as biofuel, soap, varnish making, food coloring, flavoring, dyes, medicines and bird feed (Golkar, 2014; Kumar et al., 2016). With the development of global changes, researchers from all over the world increasingly pay attention to drought as a major abiotic stress limiting growth and productivity of crops. Iran is known as one of the highest genetic diversity for safflower in the world (Knowles, 1969). It hosts a large number of native landraces with improved yields in seed and oil (Golkar, 2014).

Drought can be regarded, as a major fundamental abiotic stress factor limiting and restricting the crop plants growth and production (Farooq et al., 2012 Hussain et al., 2016). So, drought stress has recently attracted increasing attention in breeding programs due to its exacerbating impact of it by climate change (Hussain et al., 2016). In drought affected regions and semi- arid agro-ecosystems, safflower is considered as a promising alternate crop due to its high adaptability to drought conditions (Omidi Tabrizi, 2006; Kar et al., 2007; Hussain et al., 2016). The yield of safflower is influenced by such different factors as location and date of planting, soil available water, air temperature, and light intensity ( $\mathrm{Da}$ jue \& Mundel, 1996), especially during its seedling and flowering stages (Hussain et al., 2016). Different environments usually have significant fluctuation on seed yield of different genotypes due to the different responses of the genotypes to environmental features including environmental stresses (biotic and abiotic).

Hence, seed yield is influenced by genotype (G), environment $(\mathrm{E})$ and genotype $\times$ environment interactions $(\mathrm{G} \times \mathrm{E})$ in a number of genotypes that are grown in a wide range of environments (Gauch, 2006). The seed yield of safflower genotypes varies a lot due to the high dependence of their yield on both genotypic and environmental conditions (Omidi Tabrizi, 2006; Ebrahimi et al., 2016). In safflower breeding programs, interpretation of $\mathrm{G} \times \mathrm{E}$ interactions plays a major role to identify the superior genotypes across various environments (Pourdad \& Mohammadi, 2008). Also, the obtained results from $G \times E$ analysis determine the phenotypic stability of genotypes in each tested environment (Abdulahi et al., 2009). In such situations, the breeder is often faced with the choice either to develop some special genotypes for a specific adaptations and/or to choose the genotypes with a high general adaptations that can perform well in a wide range of environments (Pourdad \& Mohammadi, 2008) Thus, it is necessary to study the adaptability and stability of new genotypes with diverse origins for cultivation in different planting dates and moisture regimes in its cultivation regions as Iran.

Different methods have been commonly used to determine the extent of $\mathrm{G} \times \mathrm{E}$ interaction effects under different growing conditions (Becker \& Leon, 1988). These methods include multivariate analysis (Gauch, 2006), parametric methods (Eberhart \& Russell, 1966), and non-parametric ones (Thennarasu, 1995). Parametric methods, as the most common approach, depend on assumptions made regarding the distributional patterns of about genotypic, environmental, and $\mathrm{G} \times \mathrm{E}$ interaction effects (Huehn, 1996). The most common ones include regression coefficient $\left(b_{\mathrm{i}}\right)$ (Eberhart \& Russell, 1966), regression coefficient $\left(B_{i}\right)$ (Perkins \& Jinks, 1968), variance of deviations from regression $\left(\mathrm{s}_{\mathrm{di}}^{2}\right)$ (Eberhart \& Russell, 1966), Wricke' s ecovalance $\left(W_{i}^{2}\right)$ (Wricke, 1962), coefficient of variability $\left(\mathrm{CV}_{\mathrm{i}}\right)$ (Francis \& Kannenberg, 1978), and stability variance () (Shukla, 1972). Most breeding programs exploit combinations of some parametric and some non- parametric approaches (Becker \& Leon, 1988). Non-parametric approaches are based on no assumption about the distribution of model residuals and homogeneity of variances (Nassar \& Huehn, 1987; Farshadfar et al., 2012). Multivariate techniques have been commonly employed in stability analysis in order to provide more information regarding the real multivariate response of genotypes to different environments (Purchase et al., 2000). Multivariate analysis serves three purposes: (i) to remove noise from the data pattern, (ii) to make a summary of the data, and (iii) to show the structure existing in the data. Additive main effects and multiplicative interactions (AMMI) model combines the main effects and interactions of genotype by environment. This method have its own capacities as identification of the ideal test conditions, choice of genitors, and formulation of recommendations for regionally adapted cultivars (Gauch \& Zobel, 1996; Ebdon \& Gauch, 2002). The AMMI stability value (ASV) was developed by Purchase et al. (2000) based on the AMMI model scores (IPCA and IPCA $_{2}$ ) for each genotype. The ability of safflower varieties to function appropriately in different environmental conditions has been well confirmed by plant breeders and agronomists. The present study is intended to identify the potential of native and exotic safflower genotypes for cultivation in arid and semi-arid regions based on the best sowing dates. So, the main objective of this study was to investigate the genotype by environment interactions for the seed yield of safflower genotypes, as evaluated under different environmental conditions (year, sowing date, and moisture regimes) and 2) to find stable safflower 
genotypes having high seed yields in a wide range of environments.

\section{MATERIALS AND METHODS}

This experiment was conducted in 2016 and 2017 at the Research Farm located at Isfahan University of Technology, in Lavark, Isfahan $\left(32^{\circ} 32^{\prime} \mathrm{N}, 51^{\circ} 23^{\prime} \mathrm{E}, 1630 \mathrm{~m}\right.$ asl), Iran. The soil at the site is silty clay loam with the $\mathrm{pH}$ value of 7.8. In each of the study years, fifteen safflower accessions from various topographical regions (both na- tive and exotic accessions) were planted (Table 1) with three replications at each of the two dates designated as early sowing (15 March) and late sowing (15 April). Plants were irrigated uniformly at the budding stage. The non-stress treatment involved irrigation when $40 \%$ of the total available water was depleted from the root zone. In the medium and high drought stress treatments, irrigation was applied when depletion of $60 \%$ and 85 of the total available water from the root zone occurred, respectively. Irrigation depth was determined using the formulae: $\left.\mathrm{I}=\left[\left(\theta_{\mathrm{FC}}-\theta_{\mathrm{i}}\right) / 100\right] \mathrm{D} \times \mathrm{B}\right)$, where, $\mathrm{I}$ is the irrigation depth $(\mathrm{cm})$ and $\theta_{\mathrm{FC}}(-0.03 \mathrm{MPa})$ denotes the soil

Table 1: Safflower genotype origins and the environmental characteristics of the environments used to analyze genotype $\times$ environment interaction on safflower seed yield using parametric and nonparametric measures

\begin{tabular}{|c|c|c|c|c|}
\hline \multicolumn{5}{|c|}{ Genotype characteristics } \\
\hline Genotype & Name & Origin & Genotype type & Mean seed yield (g/plant) \\
\hline $\mathrm{G}_{1}$ & AC Sunset & Canada & - & 13.72 \\
\hline $\mathrm{G}_{2}$ & KMP30 & Karaj, Iran & Selected from mutation & 15.94 \\
\hline $\mathrm{G}_{3}$ & $\mathrm{GE}_{62918}$ & Germany & - & 11.45 \\
\hline $\mathrm{G}_{4}$ & Mex.7-37 & Mexico & - & 9.30 \\
\hline $\mathrm{G}_{5}$ & KMP51 & Karaj, Iran & Selected from mutation & 12.20 \\
\hline $\mathrm{G}_{6}$ & $\mathrm{C}_{111}$ & Isfahan, Iran & Selected from landrace & 13.43 \\
\hline $\mathrm{G}_{7}$ & $\mathrm{~K}_{21}$ & Kordestan, Iran & Selected from landrace & 9.91 \\
\hline $\mathrm{G}_{8}$ & Padideh & Isfahan, Iran & Selected from landrace & 12.51 \\
\hline $\mathrm{G}_{9}$ & IL.111 & Auromieh, Iran & Selected from landrace & 14.46 \\
\hline $\mathrm{G}_{10}$ & Mex.295 & Mexico & Pedigree method & 17.22 \\
\hline $\mathrm{G}_{11}$ & Mex.117 & Mexico & - & 11.56 \\
\hline $\mathrm{G}_{12}$ & $\mathrm{~A}_{2}$ & Azerbayejan, Iran & - & 13.24 \\
\hline $\mathrm{G}_{13}$ & Gol Sefid & Isfahan, Iran & Selected from landrace & 14.77 \\
\hline $\mathrm{G}_{14}$ & PI-25090 & Turkey & - & 8.91 \\
\hline $\mathrm{G}_{15}$ & Golmehr & Isfahan, Iran & Zarghan $279 \times$ IL. 111 & 18.42 \\
\hline
\end{tabular}

Environment characteristics

\begin{tabular}{lll}
\hline Environment & Year- Location- Sowing date-Irrigation treatment & Mean seed yield /plant (g/plant) \\
\hline $\mathrm{E}_{1}$ & 2016- Lavark- 15 March- Non-drought stress & 18.56 \\
$\mathrm{E}_{2}$ & 2016- Lavark- 15 March - Medium drought stress (60 \% FC) & 13.63 \\
$\mathrm{E}_{3}$ & 2016- Lavark- 15 March- High drought stress (85 \% FC) & 13.93 \\
$\mathrm{E}_{4}$ & 2016- Lavark- 15 April- Non-drought stress & 12.51 \\
$\mathrm{E}_{5}$ & 2016- Lavark- 15 April- Medium drought stress (60 \% FC) & 9.13 \\
$\mathrm{E}_{6}$ & 2016- Lavark- 15 April- High drought stress (85\% FC) & 8.24 \\
$\mathrm{E}_{7}$ & 2017- Lavark- 15 March- Non-drought stress & 21.78 \\
$\mathrm{E}_{8}$ & 2017- Lavark- 15 March - Medium drought stress (60 \% FC) & 14.51 \\
$\mathrm{E}_{9}$ & 2017- Lavark- 15 March High - drought stress (85\% FC) & 13.76 \\
$\mathrm{E}_{10}$ & 2017- Lavark- 15 April- Non-drought stress & 13 \\
$\mathrm{E}_{11}$ & 2017- Lavark- 15 April- Medium drought stress (60 \% FC) \\
$\mathrm{E}_{12}$ & 2017- Lavark- 15 Apri- High drought stress (85\% FC) & 9.83 \\
\hline
\end{tabular}


gravimetric moisture percentage at field capacity (22\%); on the other hand, $\theta_{i}(-1.5 \mathrm{MPa})$ indicates the soil gravimetric moisture percentage at the irrigation time (10\%), $\mathrm{D}$ refers to the root-zone depth $(50 \mathrm{~cm})$, and $\mathrm{B}$ relates to the soil bulk density at the root zone $\left(1.3 \mathrm{~g} \mathrm{~cm}^{-3}\right)$ (Clarke et al., 2008). The characteristics of the different genotypes and environments used in this study are reported in Table 2 .

\subsection{STATISTICAL ANALYSIS}

\subsubsection{Variance analysis}

For detection the magnitude effects of genotype, environment and genotype $\times$ environment, a combined analysis of variance carried out, based in three replication in each environment. The soft ware GEA-R (v.4.1) (Pacheco et al., 2015) were used for all of the calculations.

\subsubsection{AMMI analysis}

The additive main effects as well as multiplicative interaction (AMMI) model were employed according to the following formula (Gauch \& Zobel, 1996):

$y_{i j k}=\mu+g_{i}+e_{i}+\sum_{n=1}^{N} \delta_{n} \xi_{i n} \mathrm{n}_{j n}+\theta_{i j}+\varepsilon_{i j k}$

where, $\mu$ represents the grand mean, $g_{i}$ refers to the main effect of the $i^{\text {th }}$ genotype, and $e_{j}$ denotes the main effect of the $j^{\text {th }}$ environment. GEI is captured by:

$$
\sum_{n=1}^{N} \delta_{n} \xi_{i n} \mathrm{n}_{j n}
$$

In this equation, represents the Eigen value of the $n^{\text {th }}$ interaction principal component analysis (IPCA) which is retained in the AMMI model, refers to the eigen vector taken for the $i^{\text {th }}$ genotype from the $n^{\text {th }}$ IPCA, indicates the Eigenvector considered for the $j^{\text {th }}$ environment from the $n^{\text {th }}$ IPCA, indicates the GEI residual, $\mathrm{n}$ shows the number of IPCA kept in the model and finally, $\mathrm{e}_{\mathrm{ijK}}$ stands for the random error term.

\subsubsection{Parametric statistics}

1) Coefficient of variation (C.V)

Coefficient of variability (CVi) and mean yield (Francis \& Kannenberg, 1978) were used to measure the stability of each genotype. Genotypes with low CVs and high average yields were considered as the most desirable ones.

$$
C V i=\left(\sqrt{\delta^{2}} / \bar{X} i .\right) \times 100
$$

2) Regression approaches

Eberhart and Russell (1966) used the linear regression coefficient (bi) (a part) and pooled deviation mean squares ( (b section) to study the $\mathrm{G} \times \mathrm{E}$ interaction.

$(a) b=1+\frac{\sum_{i}(X i j-\bar{X} i .-\bar{X} . j+\bar{X} . .)(\bar{X} . j-\bar{X} . .)}{\sum_{j}(\bar{X} . j-\bar{X} . .)^{2}}$

(b) $\delta_{d i}^{2}=\frac{\sum\left[X i j-\bar{X} i .-\bar{X} . j+\bar{X}_{. .}\right]-b_{i}{ }^{2} \sum_{j=1}^{q}\left(X_{s}-X_{i_{s}}\right)^{2}}{e-2}-\frac{\delta_{\theta}^{2}}{r}$

According to Perkins and Jinks (1968), the stable variety in each genotype is defined by small values of $D_{i j}$ and non-significance of $B_{i}=1$.

$B i=\frac{\sum_{j}\left(X_{i j}-\bar{X} i .-\bar{X} \cdot j+\bar{X}_{. .}\right)\left(\bar{X}_{. j}-\bar{X}_{. .}\right)}{\sum_{j}(\bar{X} \cdot j-\bar{X} \cdot .)^{2}}$

$\mathrm{D}_{\mathrm{ij}}$

3) Coefficient of determination $\left(R^{2}\right)$

The most stable genotype is characterized by the minimum value of $\mathrm{R}^{2}$ (Pinthus, 1973).

$R_{i}^{2}=\frac{b_{i}^{2} \sum_{i}\left(\bar{X}_{i j}-\bar{X} . .\right)^{2}}{\sum_{j}\left(\bar{X}_{i j}-\bar{X} i .\right)^{2}}$

Here, $X_{i j}$ represents the safflower yield of the genotype $i$ in the environment $j, X_{i}$ denotes the mean safflower yield of the genotype $i, X_{j}$ stands for the mean safflower yield in the environment $j, X$.. is the grand mean, $b_{i}$ denotes the regression coefficient, $e$ is taken as the number of environments and finally, $g$ indicates the genotypes number. Wricke covalence $\left(\mathrm{W}_{\mathrm{i}}^{2}\right)$

$W_{i}^{2}=\sum_{j}^{e}\left(X_{i j}-\frac{X_{i}}{e}-\frac{X_{j}}{g}+\frac{X_{-}}{g e}\right)^{2}$

4) Shukla's stability variance parameter $\left(\delta_{i}^{2}\right)$.

Then, estimation of the unbiased stability for each genotype was determined using Shukla's stability variance (Shukla, 1972):

$\delta_{i}^{2}=\left(\frac{p}{(p-2)(q-1)}\right) W_{i}^{2}-\frac{S S G E}{(p-1)(q-1)(p-2)}$ 
With this statistics, the most stable genotype is the one that minimizes $\left(\delta_{i}^{2}\right)$.

5) Superiority index $(P i)($ Lin \& Binns, 1988)

$$
\boldsymbol{P}_{i}=\frac{\sum_{1}^{n}(X i j-M j)^{2}}{2 e}
$$

where, $X_{i j}$ is the safflower yield of genotype $i$ in environment $j, M_{j}$ is the safflower yield of the reference genotype in environment $j$, and $e$ is the number of environments.

\section{6) AMMI stability value (ASV)}

For each genotype and each environment, the AMMI stability value (ASV) is estimated on the basis of the relative contribution of IPCA to IPCA scores (the interaction principle component axes 1 and 2 , respectively) and can be applied to the interaction sum of squares (ss), which is as follows (Purchase et al., 2000)

$$
A S V i=\sqrt{\left[\frac{S S_{I P C A 1}}{S S_{I P C A 2}}(I P C A 1 \text { score })^{2}\right]+(\text { IPCA2 score })^{2}}
$$

\section{$S S_{I P C A 1}$}

where, $\overline{S S_{I P C A z}}$ is the weight given to the IPCA-1 value. Smaller IPCA scores represent a more stable genotype in different environments.

\subsubsection{Non-parametric measures}

In this study, the following two non-parametric stability statistics are derived on the basis of genotypes yield rank in each environment $(\mathrm{m}=$ number of environments) (Nassar \& Huehn, 1987; Huehn, 1996):

$$
\begin{aligned}
& S_{i}^{(1)}=2 \sum_{\mathrm{j}}^{\mathrm{m}-1} \sum_{\mathrm{i}=\mathrm{j}+1}^{\mathrm{n}}\left|\mathrm{r}_{\mathrm{ij}}-\mathrm{r}_{\mathrm{ij}}\right| /[\mathrm{m}(\mathrm{m}-1)] \\
& S_{i}^{(2)}=\sum_{j=1}^{m}\left(r_{i j}-\bar{r}_{i .}\right)^{2} /(m-1)
\end{aligned}
$$

Non-parametric stability measures were calculates as follows (Thennarasu (1995):

$$
\begin{aligned}
& N P_{i}^{(1)}=\frac{1}{m} \sum_{j=1}^{n}\left|r_{i j}^{*}-M_{d i}^{*}\right| \\
& N P_{i}^{(2)}=\frac{1}{m}\left(\sum_{j=1}^{n}\left|r_{i j}^{*}-M_{d i}^{*}\right|, M_{d i}\right)
\end{aligned}
$$

$N P_{i}^{(3)}=\frac{\sqrt{\sum\left(r_{i j}^{*}-\overline{r_{i}^{*}}\right)^{2}}}{\bar{r}_{i .}}$

$N P_{i}^{(4)}=\frac{2}{m(m-1)}\left[\sum_{j}^{m-1} \sum_{(j=j+1)}^{m}\left|r_{i j}^{*}-r_{i j}^{*}\right| / \bar{r}_{i}\right]$

The different stability parameters were statistically compared in this study by employing Spearman's coefficient of rank correlation ( $r_{s}$ ) (Steel \& Torrie, 1980). Furthermore, the significance of ranks was tested for the studied genotypes using Kruskal-Wallis $H$ test (Kruskal \& Walis, 1952).For a test of genotypic differences, the test statistic $(\mathrm{H})$ is almost $X^{2}$ - distributed, with degrees of freedom being $\mathrm{g}-1$.

\section{RESULTS}

\subsection{ANALYSIS OF GENOTYPE $\times$ ENVIRONMENT INTERACTION BY AMMI MODEL}

The AMMI model revealed that the seed yield was considerably influenced through genotype, environment, and genotype $\times$ environment interaction (Table 2). AMMI analysis of variance partitioned the GE interaction into three interaction principal component axes (IPCA), all of which were significant for seed yield, while the three first principal components explained $92.61 \%$ of the GE interaction. Based on this analysis, of the total sum of squares, $52.65 \%$ could be attributed to the environmental effects; these included $25.34 \%$, which could be attributed to genotypic effects and $22 \%$, which could be related to GEI effects for seed yield.

The biplot showed that genotypes $\mathrm{G}_{6}$ and $\mathrm{G}_{10}$ had the lowest IPCA1 scores (Figure 1). Given the angle that is estimated between the genotype $i$ vectors and the environment $j$, the interaction effect $(\mathrm{G} \times \mathrm{E})$ could be assumed to be positive for acute angles, while it is expected to be negligible for right angles; also, it can be postulated to be negative for obtuse angles. So, $G_{9}$ and $G_{4}$ showed to be specifically adaptable to the best environments including $\mathrm{E}_{7}$ (i.e., non-drought stress condition with the early sowing date in 2017) and $\mathrm{E}_{1}$ (i.e., non- drought stress condition with the early sowing date in 2016) (Figure 1). The genotypes $G_{8}$ and $G_{15}$ showed to be specifically adaptable to environment E5 (i.e., medium drought stress with the early sowing date in 20165) and $\mathrm{E}_{11}$ (i.e., medium drought stress with the early sowing date in 2016) (Figure 1). In the worst environments for seed yield (i.e., $\mathrm{E}_{6}$ and $\mathrm{E}_{12}$ ), $\mathrm{G}_{14}$ showed the highest specific adaptation (Figure 
Table 2: AMMI analysis of variance (a) and the first two AMMI scores for 15 safflower genotypes across 12 environments

\begin{tabular}{|c|c|c|c|c|c|}
\hline Source of variation & DF & \multicolumn{4}{|c|}{ MS Seed yield (g/ plant ) } \\
\hline Environment ( E) & 11 & \multicolumn{4}{|l|}{$727.75^{* \star}$} \\
\hline Genotype (G) & 14 & \multicolumn{4}{|l|}{$275.22^{* *}$} \\
\hline $\mathrm{G} \times \mathrm{E}$ & 154 & \multicolumn{4}{|l|}{$21.73^{* *}$} \\
\hline IPCA1 & 24 & \multicolumn{4}{|l|}{$71.89^{* *}$} \\
\hline IPCA2 & 22 & \multicolumn{4}{|l|}{$38.48^{* *}$} \\
\hline IPCA3 & 20 & \multicolumn{4}{|l|}{$26.44^{* *}$} \\
\hline Noise & 88 & \multicolumn{4}{|l|}{2.8} \\
\hline \multirow[t]{2}{*}{ Error } & 360 & \multicolumn{4}{|l|}{17.52} \\
\hline & \multicolumn{3}{|c|}{ Genotypic scores } & \multicolumn{2}{|c|}{ Environmental scores } \\
\hline Genotype & IPCA1 & IPCA2 & Environment & IPCA1 & IPCA2 \\
\hline G1 & -0.28 & -0.04 & E1 & -0.74 & -0.65 \\
\hline G2 & 0.20 & 0.091 & E2 & -0.161 & 0.69 \\
\hline G3 & -0.40 & -0.33 & E3 & -0.38 & 0.22 \\
\hline G4 & -0.30 & 0.061 & $\mathrm{E} 4$ & 0.34 & 0.13 \\
\hline G5 & 0.41 & 0.07 & E5 & 0.98 & -0.32 \\
\hline G6 & -0.04 & 0.427 & E6 & -0.10 & -0.17 \\
\hline G7 & -0.50 & 0.707 & E7 & -0.58 & -0.71 \\
\hline G8 & 0.66 & -0.0097 & E8 & -0.18 & 0.65 \\
\hline G9 & -1 & -0.587 & E9 & -0.29 & 0.40 \\
\hline G10 & 0.10 & -0.077 & E10 & 0.26 & 0.20 \\
\hline G11 & 0.46 & -0.66 & E11 & 1 & -0.29 \\
\hline G12 & 0.20 & 0.35 & E12 & -0.13 & -0.13 \\
\hline G13 & -0.15 & 0.64 & & & \\
\hline G14 & -0.15 & 0.64 & & & \\
\hline G15 & 0.90 & -0.17 & & & \\
\hline
\end{tabular}

1). Genotypes and environments away from the center of the biplot showed large $\mathrm{G} \times \mathrm{E}$ interactions, displaying some specific kind of adaptation. Genotypes which were near the origin, including $G_{6}$ and $G_{10}$, were found to have large stability statistics (Figure 2). Considering its high seed yield, $G_{10}$ had the most specific adaptation to environments $\mathrm{E}_{1}$ and $\mathrm{E}_{7}$ (Figure 1).

The Heat Map graph in Figure (2) was drawn to gain a better understanding of the genotypic clustering based on their seed yield performance (g/plant) in different environments. Clearly, the environments may be divided into three different groups including favorable $\left(\mathrm{E}_{7}\right.$ followed by $\left.\mathrm{E}_{1}\right)$, medium $\left(\mathrm{E}_{2}, \mathrm{E}_{3}, \mathrm{E}_{4}, \mathrm{E}_{8}, \mathrm{E}_{9}\right.$ and $\left.\mathrm{E}_{10}\right)$, and unfavorable $\left(\mathrm{E}_{12}\right.$ followed by $\mathrm{E}_{5}, \mathrm{E}_{6}$ and $\mathrm{E}_{11}$ ) environments (Figure 2). Also, the genotypes can be categorized into high $\left(G_{4}, G_{9}\right.$ and $\left.G_{10}\right)$, intermediate $\left(G_{1}, G_{3}, G_{6}, G_{7}, G_{13}\right.$ and $\left.G_{14}\right)$, and low yield $\left(G_{8}\right.$ and $\left.G_{12}\right)$ ones. In the heat map legend, six different color represented different ranges of seed yield (g/plant) from $\mathrm{E}_{1}$ to $\mathrm{E}_{12}$, demonstrating the relative seed yield of each genotype in different environments.

\subsection{PARAMETRIC MEASUREMENTS}

Seed yield (SY) was used as the first parameter to evaluate the genotypes; thus, the genotypes $G_{4}, G_{9}$ and $G_{10}$ were identified as the one with the highest but $G_{8}$ and $G_{12}$ as those with the lowest mean yields across the 12 environments (Table 3 ). Moreover, the genotypes $G_{1}, G_{3}$, $\mathrm{G}_{4}, \mathrm{G}_{7}$ and $\mathrm{G}_{9}$ recording regression coefficients $\left(b_{i}\right)$ higher than unity exhibited yield performances greater than the average and were found adaptable to favorable environments, whereas the remaining ones with $b$, values less than unity recorded the least average yields, which could be hardly adapted to all environments, and could only have specific adaptation to low yielding environments. Regarding stability parameters, the least values for $\mathrm{W}^{2} \mathrm{i}$, 


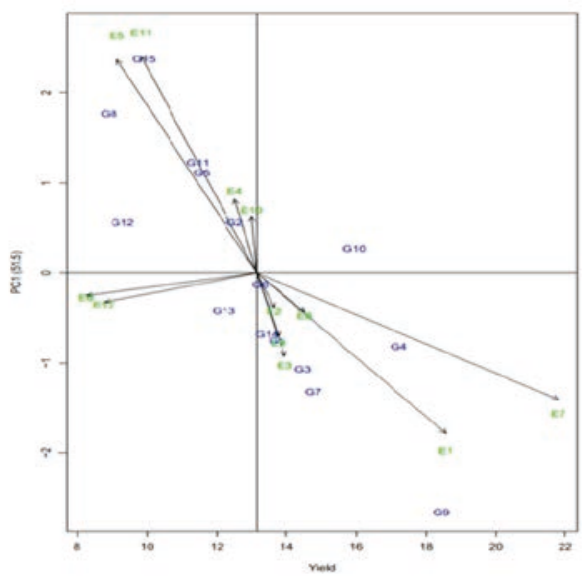

Figure 1: Biplot of mean seed yield (g/plant) for safflower and first IPCA axis (AMMI1) of the safflower genotypes grown in different environments

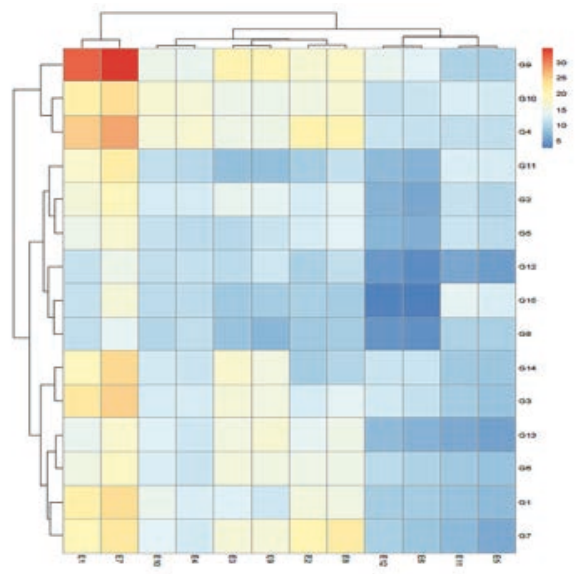

Figure 2: Heat map graph showing the clustering of the 15 safflower genotypes studied across 12 environments based on their yield performance (g/plant)

CV, $\mathrm{D}_{\mathrm{ij}}$, and ASV were denoted to $\mathrm{G}_{10}$ (Table 3). Comparison of ranks of yield means identified $G_{10}$ and $G_{9}$ as the one with the least (4.09) and highest (11.36) mean yields, indicating the highest and least yield stability measures, respectively (Table 3 ).

\subsection{NON-PARAMETRIC MEASUREMENTS}

Table 4 reports the results of non-parametric stability statistics $\left(\mathrm{Si}^{(1)}\right.$ and $\left.\mathrm{Si}^{(2)}\right)$ due to Thennarasu (1995) calculated based on the ranks of adjusted yield means. The non-parametric methods identified G12 with $\mathrm{Si}^{(1)}$, $\mathrm{Si}^{(2)}, \mathrm{NPi}^{(2)}, \mathrm{NPi}^{(3)}$, and $\mathrm{NPi}^{(4)}$ ranks as the most stable genotype for seed yield among the studied genotypes, whereas $\mathrm{G}_{9}$ with $\mathrm{Si}^{(1)}, \mathrm{NPi}^{(2)}, \mathrm{NPi}^{(3)}$, and $\mathrm{NPi}^{(4)}$ ranks was found to be the most unstable one but ranking the best for seed yield. With respect to $\mathrm{NPi}{ }^{(1)}$, the most stable and non-stable genotypes were $\mathrm{G}_{2}$ and $\mathrm{G}_{14}$, respectively. The highest (12.42) and the least (3) means of ranks belonged to $\mathrm{G}_{14}$ and $\mathrm{G}_{12}$ genotypes, respectively (Table 4). The significance tests for $\mathrm{Si}^{(1)}$ and $\mathrm{Si}^{(2)}$ were conducted by calculating the $Z_{i}$ values (Nassar and Huehn, 1987) on the basis of the ranks of the adjusted data; then they were summed up over the genotypes (Table 4). No significant differences were found among the 15 genotypes grown in the 12 environments in regard to rank stability; this was because as both these statistics recorded values less than the critical value of $\mathrm{X}^{2}{ }_{0.05}, \mathrm{df}=15=24.99$. Among the individual $\mathrm{Z}$ values, none of the genotypes was shown to be considerably unstable, in comparison to others, with the exception of $\mathrm{G}_{15}$ with a $\mathrm{Zi}^{(2)}$ greater than the critical value of $\mathrm{X}_{0.05}^{2}, 1=3.84$ ).

To gain a better understanding of the rank means 


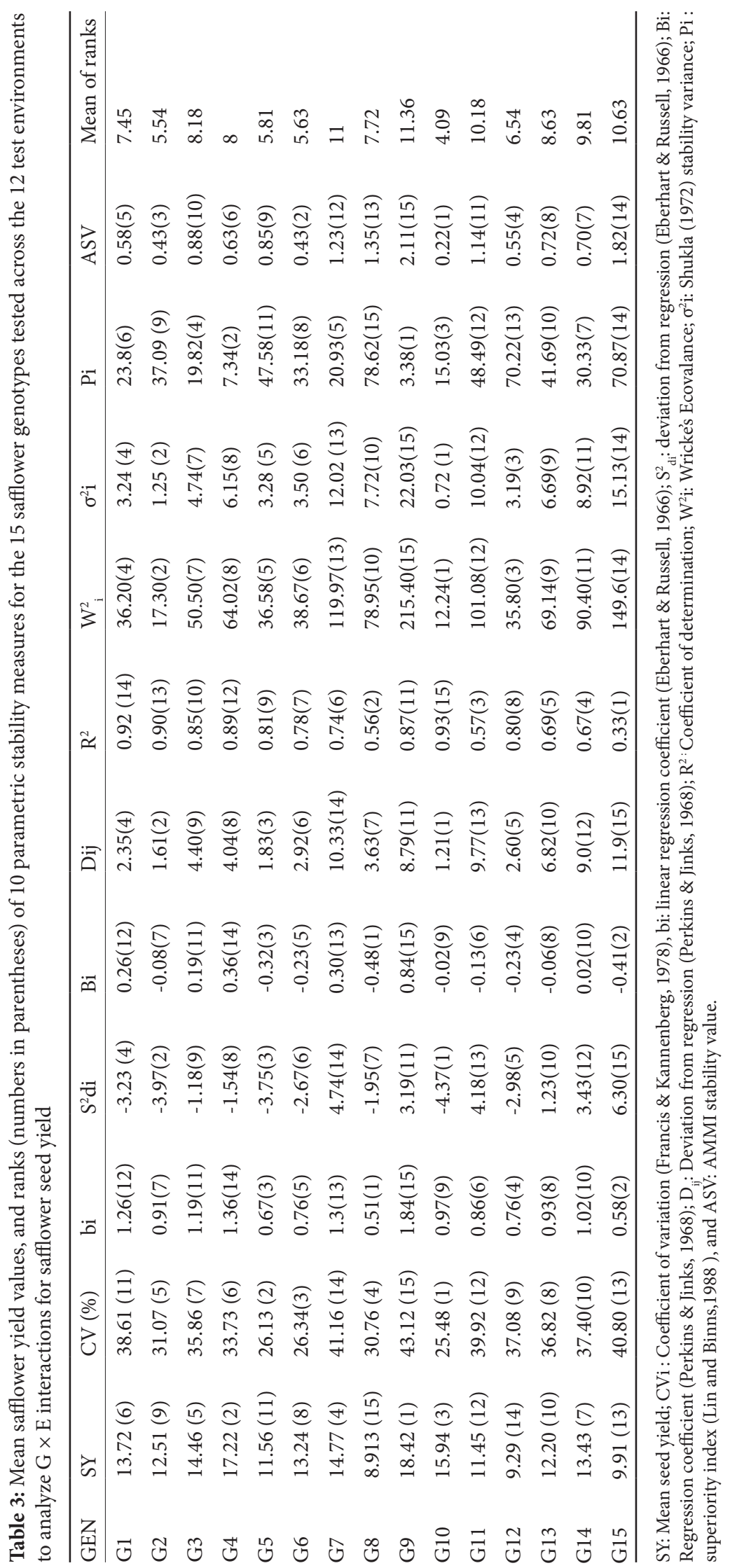




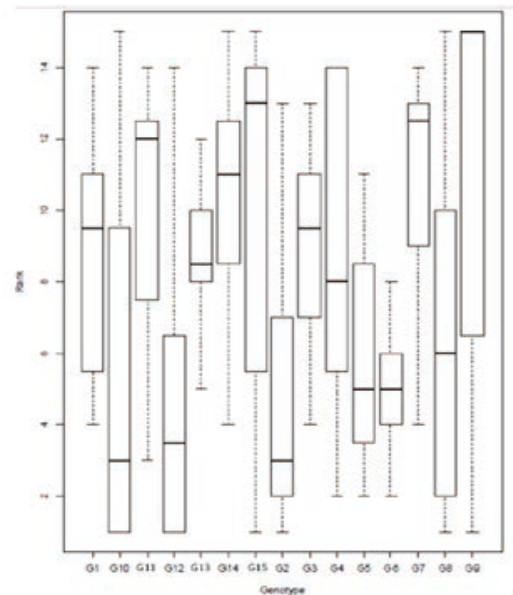

Figure 3: Box and whisker plot of rank means for the genotypes evaluated at the twelve locations in this study. In the case of each genotype, a box is the interquartile range, a heavy horizontal line indicates the median; on the other hand, fine horizontal lines show the minimum and maximum values with the exclusion of the outliers and extreme values.

Table 4: Mean yield values and ranks (numbers in parentheses) of the non-parametric stability parameters for the 15 genotypes over the 12 environments investigated.

\begin{tabular}{|c|c|c|c|c|c|c|c|c|c|c|}
\hline Genotype & $\begin{array}{l}\text { SY } \\
\text { (g/plant) }\end{array}$ & $\mathrm{Si}(1)$ & $\mathrm{Zi}(1)$ & $\operatorname{Si}(2)$ & $\mathrm{Zi} \mathrm{(2)}$ & $\mathrm{NPi}^{(1)}$ & $\mathrm{NPi}^{(2)}$ & $\mathrm{Npi}^{(3)}$ & $\mathrm{NPi}^{(4)}$ & $\begin{array}{l}\text { Ranks } \\
\text { mean }\end{array}$ \\
\hline G1 & $13.72(6)$ & $0.76(11)$ & 0.39 & $10.18(10)$ & 0 & $2.66(10)$ & $0.41(9)$ & $0.41(7)$ & $0.11(10)$ & 9 \\
\hline G2 & $12.51(9)$ & $0.39(2)$ & 0.97 & $4.82(3)$ & 0.67 & $1.41(1)$ & $0.15(3)$ & $0.23(3)$ & $0.04(3)$ & 3.42 \\
\hline G3 & $14.46(5)$ & $0.76(12)$ & 0.39 & $8.82(9)$ & 0.04 & $2.41(9)$ & $0.48(13)$ & $0.48(10)$ & $0.12(12)$ & 10 \\
\hline G4 & $17.22(2)$ & $0.47(6)$ & 0.40 & $5(5)$ & 0.63 & $1.75(4)$ & $0.7(14)$ & $0.61(14)$ & $0.15(14)$ & 8.42 \\
\hline G5 & $11.56(11)$ & $0.62(8)$ & 0 & $8.18(8)$ & 0.09 & $1.83(7)$ & $0.16(4)$ & $0.27(5)$ & $0.06(4)$ & 6.71 \\
\hline G6 & $13.24(8)$ & $0.42(4)$ & 0.73 & $4.27(2)$ & 0.82 & $1.75(5)$ & $0.26(6)$ & $0.25(4)$ & $0.07(5)$ & 4.85 \\
\hline G7 & $14.77(4)$ & $0.68(9)$ & 0.07 & $14.55(12)$ & 0.46 & $2.83(13)$ & $0.43(11)$ & $0.57(13)$ & $0.11(9)$ & 10.14 \\
\hline G8 & $8.913(15)$ & $0.45(5)$ & 0.52 & $8(7)$ & 0.11 & $1.83(8)$ & $0.12(2)$ & $0.2(2)$ & $0.03(2)$ & 5.85 \\
\hline G9 & $18.42(1)$ & $0.52(7)$ & 0.17 & $5.91(6)$ & 0.42 & $1.75(6)$ & $0.87(15)$ & $0.84(15)$ & $0.18(15)$ & 9.28 \\
\hline G10 & $15.94(3)$ & $0.40(3)$ & 0.97 & $4.91(4)$ & 0.65 & $1.66(3)$ & $0.41(10)$ & $0.50(11)$ & $0.11(11)$ & 6.42 \\
\hline G11 & $11.45(12)$ & $0.85(13)$ & 1.04 & 19.64(14) & 2.15 & $3.33(14)$ & $0.31(7)$ & $0.42(9)$ & $0.08(8)$ & 11 \\
\hline G12 & $9.29(14)$ & $0.24(1)$ & 2.68 & $3(1)$ & 1.22 & $1.41(2)$ & $0.10(1)$ & $0.12(1)$ & $0.02(1)$ & 3 \\
\hline G13 & $12.20(10)$ & $0.7(10)$ & 0.13 & $12.64(11)$ & 0.14 & $2.75(12)$ & $0.32(8)$ & $0.38(6)$ & $0.08(7)$ & 9.14 \\
\hline G14 & $13.43(7)$ & $1.02(15)$ & 3.10 & $17.18(13)$ & 1.18 & $3.58(15)$ & $0.44(12)$ & $0.52(12)$ & $0.13(13)$ & 12.42 \\
\hline G15 & $9.91(13)$ & $0.97(14)$ & 2.38 & $25.09(15)$ & 5.34 & $2.66(11)$ & $0.20(5)$ & $0.41(8)$ & $0.08(6)$ & 10.28 \\
\hline \multirow{2}{*}{\multicolumn{2}{|c|}{ Test statistics }} & \multicolumn{2}{|c|}{$\mathrm{E}\left(\mathrm{Si}^{(1)}\right)=0.616$} & \multicolumn{2}{|c|}{$\mathrm{E}\left(\mathrm{Si}^{(2)}\right)=10.14$} & & & & & \\
\hline & & \multicolumn{2}{|c|}{$\operatorname{Var}\left(\mathrm{Si}^{(1)}\right)=0.052$} & \multicolumn{2}{|c|}{$\operatorname{Var}\left(\mathrm{Si}^{(2)}\right)=41.75$} & & & & & \\
\hline
\end{tabular}

for the genotypes evaluated, the box and whisker plot shown in Figure 3 was used. The median, upper, and lower quartiles and interquartile range for the mean of ranking (both parametric and non-parametric methods) are depicted for each genotype in this graph. The least rank mean (4.62) was observed for $G_{2}$ and $G_{12}$ genotypes, showing no significant differences from $G_{6}$ and $\mathrm{G}_{10}$ (Figure 2). The highest rank mean (11.12) was denoted to $G_{9}$. The genotypes $G_{1}, G_{3}, G_{4}, G_{7}, G_{11}, G_{13}$, $G_{14}$, and $G_{15}$ showed no significant differences in their rank means (Figure 2). The test of significant differences among the ranks of genotypes for all the stability parameters revealed an $\mathrm{H}$ value) 63.37) greater than the critical value of $X_{(005,14)}^{2}=23.68$, revealing the significant differences between the genotypes studied in regards to rank stability. 


\subsection{ASSOCIATION AMONG THE PARAMETRIC AND NON-PARAMETRIC MEASURES}

Each of the parameters mentioned above produced a genotype order (Tables 3 and 4). Correlations between the ranks were then calculated and a PC analysis was performed based on this rank correlation (Table 5 and Figure 4). The Spearman's rank correlations between parametric and non-parametric measures are reported in Table 5. Clearly, the mean yields were significantly and negatively correlated with the stability measures of bi, $\mathrm{R}^{2}$,
$\mathrm{D}_{\mathrm{ij}}, \mathrm{NPi}{ }^{2)} \mathrm{NPi}^{(3)}$, and $\mathrm{NPi}^{(4)}$ (Table 5), but significantly and positively correlated with $\mathrm{Pi}\left(\mathrm{r}=0.99^{* *}\right)$. The C.V parameter showed positive and significant correlations with $s_{\text {di }}^{2}, \sigma_{i}^{2}, \mathrm{~W}_{\mathrm{i}}, \mathrm{Si}^{(1)}, \mathrm{Si}^{(2)}, \mathrm{NPi}^{(1)}$, and ASVI (Table 5). The regression coefficient (bi) established a negative and significant correlation with $\mathrm{Pi}$, but it conversely, positive and significant correlations with $\mathrm{NPi}^{(2)}, \mathrm{NPi}^{(3)}$, and $\mathrm{NPi}^{(4)}$. The $\mathrm{s}_{\mathrm{di}}$ established significant and positive correlations with $\sigma_{i}^{2}, \mathrm{~W}_{\mathrm{i}}, \mathrm{ASVI}, \mathrm{Si}^{(1)}, \mathrm{Si}^{(2)}, \mathrm{NPi}^{(1)}$, and $\mathrm{NPi}^{(4)}$. The superiority index $(\mathrm{Pi})$ was negatively and significantly correlated with $\mathrm{R}^{2}, \mathrm{D}_{\mathrm{ij}}, \mathrm{NPi}^{(2)}, \mathrm{NPi}^{(3)}$, and $\mathrm{NPi}^{(4)}$ (Table 5). $\mathrm{W}_{\mathrm{i}}$

Table 5: Spearman rank correlations between mean of seed yield $\left(\mathrm{S}_{\mathrm{Y}}\right)$, stability parameters and non-parametric measures for the safflower genotypes across different environments

\begin{tabular}{|c|c|c|c|c|c|c|c|c|c|c|c|c|c|c|c|}
\hline & SY & $\mathrm{CV}$ & bi & $\mathrm{s}_{\mathrm{di}}^{2}$ & $\mathrm{R}^{2}$ & $\sigma^{2} \mathrm{i}$ & $D_{i j}$ & $\mathrm{~W}^{2} \mathbf{i}$ & $\mathrm{Pi}$ & $\operatorname{Si}(1)$ & $\operatorname{Si}(2)$ & $\mathrm{NPi}^{(1)}$ & $\mathrm{NPi}^{(2)}$ & $\mathrm{NPi}^{(3)}$ & $\mathrm{NPi}^{(4)}$ \\
\hline $\mathrm{CV}$ & -0.12 & 1 & & & & & & & & & & & & & \\
\hline bi & $-0.91^{* *}$ & 0.38 & 1 & & & & & & & & & & & & \\
\hline $\mathbf{s}_{\mathrm{di}}^{2}$ & 0.01 & $0.77^{* *}$ & 0.15 & 1 & & & & & & & & & & & \\
\hline $\mathrm{R}^{2}$ & $-0.65^{* *}$ & -0.31 & $0.54^{*}$ & $-0.70^{* *}$ & 1 & & & & & & & & & & \\
\hline$\sigma^{2} \mathrm{i}$ & -0.03 & $0.72^{* *}$ & 0.15 & $0.93^{* *}$ & $-0.66^{* *}$ & 1 & & & & & & & & & \\
\hline$D_{i j}$ & $-0.91^{* *}$ & 0.38 & 1.00 & 0.15 & $0.54^{*}$ & 0.15 & 1 & & & & & & & & \\
\hline $\mathrm{W}^{2}{ }_{\mathrm{i}}$ & -0.03 & $0.72^{* *}$ & 0.15 & $0.93^{* *}$ & $-0.66^{* *}$ & 1.00 & 0.15 & 1 & & & & & & & \\
\hline $\mathrm{Pi}$ & $0.99^{* *}$ & -0.08 & $-0.91^{* *}$ & 0.07 & $-0.69^{* *}$ & 0.03 & $-0.91^{* *}$ & 0.03 & & & & & & & \\
\hline $\mathrm{Si}^{(1)}$ & 0.00 & $0.54^{*}$ & 0.14 & $0.70^{* *}$ & $-0.47^{*}$ & $0.60^{* *}$ & 0.14 & $0.60^{* *}$ & 0.04 & & & & & & \\
\hline $\mathrm{Si}^{(2)}$ & 0.13 & $0.57^{*}$ & 0.03 & $0.74^{* *}$ & $-0.58^{*}$ & $0.66^{* *}$ & 0.03 & $0.66^{* *}$ & 0.19 & $0.93^{* *}$ & & & & & \\
\hline $\mathrm{NPi}^{(1)}$ & 0.11 & $0.55^{*}$ & 0.08 & $0.75^{* *}$ & $-0.63^{* *}$ & $0.66^{* *}$ & 0.08 & $0.66^{* *}$ & 0.15 & $0.90^{* *}$ & $0.93^{* *}$ & & & & \\
\hline $\mathrm{NPi}^{(2)}$ & $-0.89^{* *}$ & 0.34 & $0.89^{* *}$ & 0.35 & 0.31 & 0.36 & $0.89^{* *}$ & 0.36 & $-0.88^{* *}$ & 0.38 & 0.23 & 0.26 & & & \\
\hline $\mathrm{NPi}^{(3)}$ & $-0.81^{* *}$ & 0.44 & $0.80^{* *}$ & $0.48^{*}$ & 0.18 & 0.50 & $0.80^{* *}$ & 0.50 & $-0.77^{\star *}$ & 0.42 & 0.36 & 0.32 & $0.93^{* *}$ & & \\
\hline $\mathrm{NPi}^{(4)}$ & $-0.85^{* *}$ & 0.34 & $0.85^{* *}$ & 0.32 & 0.33 & 0.34 & $0.85^{* *}$ & 0.34 & $-0.84^{* *}$ & 0.43 & 0.26 & 0.27 & $0.98^{* *}$ & $0.93^{* *}$ & \\
\hline ASVI & 0.12 & $0.61^{* *}$ & 0.00 & $0.73^{*}$ & $-0.57^{*}$ & $0.86^{* *}$ & 0.00 & $0.86^{* *}$ & 0.16 & $0.52^{*}$ & $0.61^{*}$ & 0.54 & 0.17 & 0.31 & 0.15 \\
\hline
\end{tabular}

${ }^{*}$ and ${ }^{* *}$ significantly correlated at 0.05 and 0.01 , respectively.

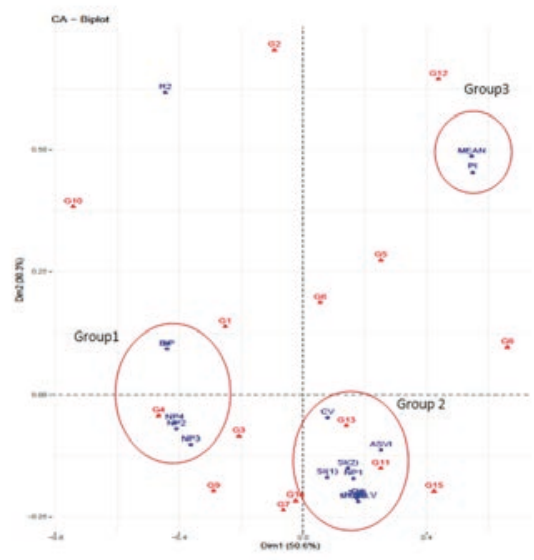

Figure 4: Biplot of the first two principal components for the studied genotypes and their ranks in terms of different parametric and non-parametric parameters. 
had positive and significant correlations with $\mathrm{Pi}, \mathrm{Si}{ }^{(1)}, \mathrm{Si}$ (2), $\mathrm{NPi}^{(1)}$, and ASVI, indicating that these measures led to similar results. Figure 4 illustrates a biplot of the first two principal components of stability ranks (PCA 1 vs. $\mathrm{PCA}_{2}$ ), which accounted for $80.95 \%$ of the variance in the original variables. Simultaneous examination of both axes discloses the presence of the following three groups: Group 1 consisting of $\mathrm{NPi}^{(2)} \mathrm{NPi}^{(3)}, \mathrm{NPi}^{(4)}$, and $\mathrm{Bi}$ (Figure 4); Group 2 composed of $\mathrm{CVi}, \mathrm{b}_{\mathrm{i}}, \mathrm{S}_{\mathrm{di}}^{2}, \mathrm{D}_{\mathrm{ij}}, \mathrm{W}_{\mathrm{i}}^{2}, \sigma_{\mathrm{i}}^{2}, \mathrm{ASV}$, $\mathrm{Si}^{(1)}, \mathrm{Si}^{(2)}$, and $\mathrm{NPi}^{(1)}$; and Group 3 comprising seed yield and $\mathrm{Pi}$ (Figure 4 ). $\mathrm{R}^{2}$ is located in a separate section of the biplot.

\section{DISCUSSION}

The interaction of genotype and environment complicates the identification of superior genotypes containing better stability across a wide range of environments (Annicchiarico, 2002). Hence, GE interactions need to be modelled and adequately interpreted for different plant species (Abdulahi et al., 2009). Stability and wide adaptation are of vital importance for semi-arid regions of highly varying characteristics. Selection of suitable planting date for safflower is a first management decision aimed at seed yield stability in safflower under arid conditions (Dajue \& Mundel, 1996; Caliskan \& Caliskan, 2018). Evaluation of safflower seed yield under different moisture conditions, multi-sowing dates, and over different years might revealed hidden trends in genotype $x$ environment interactions, thereby complicating the decisions related to selecting or recommending the more appropriate lines of the highest stability (Pourdad \& Mohammadi, 2008).

In this study, the study of genotype $\times$ environment interaction revealed the differential response of safflower genotypes to environmental conditions and showed the possibility of selecting for stable genotypes. A large proportion of the square sums for environment in our GE analysis indicated diversity among the environments studied. This finding is in agreement with those previously reported on safflower (Abdulahi et al., 2009; Moghaddam \& Pourdad, 2009; Ebrahimi et al., 2016). The biplot constructed with seed yield and IPCA for genotype and environment on the $\mathrm{X}$ and $\mathrm{Y}$ axes, respectively, can be interpreted by comparing the $i$ scores of IPCA for each genotype and environment (Gauch \& Zobel, 1996). The lowest IPCA 1 scores of the genotypes $G_{6}$ and $G_{10}$ indicate that they had the lowest interaction with environment (Figure 1). By definition, stable genotypes are the ones with the minimal variance for yield in a wide range of environments (Lin \& Binns, 1988). So, this biological concept of stability cannot be helpful to the vast majority of plant breeders as they are commonly looking genotypes having high mean yields and a good potential in order to ensure $r$ better environmental conditions (i.e., the concept of dynamic stability) (Becker \& Leon, 1988). According to Eberhart and Russell (1966), a stable variety will be one with $b_{i}=1$ and $=0$. Genotypes with $b i>1$ could be better adapted to favorable growing conditions; on the other hand, it could be argued that those with $b_{i}$ $<1$ would be adaptable to the environmental conditions that are not favorable; finally, those who regression coefficients equals unity would show an average adaptation to all environmental conditions. With this regression coefficient $\left(b_{i}\right), G_{9}$ followed by $G_{4}, G_{7}$ and $G_{3}$ would adapt to favorable environments (adequate moisture and early sowing date) (Figure 2 and Table 3). Thus, genotypes $G_{10}$ and $\mathrm{G}_{2}$ were considered as the most stable because of their least values of $\mathrm{S}^{2}{ }_{\mathrm{di}}$ and their $\mathrm{b}$ regression coefficients close to unity (Table 3). In agreement with Pinthus (1973), the genotypes $G_{9}$ and $G_{15}$ with higher coefficients of determination were considered to be unstable while $G_{10}$ followed by $G_{5}$ and $G_{6}$ that recorded the lowest coefficients of determination were categorized as stable (Table 3 ).

Regarding other parametric stability parameters, $\mathrm{G}_{10}$ recorded the least values for $\mathrm{W}_{\mathrm{i}}^{2}, \mathrm{CV}, \mathrm{D}_{\mathrm{ij}}$, and $\mathrm{ASV}$ (Table 3). Hence, this genotype could be considered as the one with the highest stability for seed yield while $G_{9}$ and $G_{15}$ were instable due to their higher values of $W^{2} i$, a parameter that had the greatest contribution to the GE interaction. Regarding the superiority index, the highest $\mathrm{P}_{\mathrm{i}}$ value was recorded by the genotypes with the largest yield difference from that of the reference genotype. It must be noted that a low value of $\mathrm{P}_{\mathrm{i}}$ indicates the relatively high stability of a cultivar. The genotype $G_{9}$ followed by $\mathrm{G}_{4}$ and $\mathrm{G}_{10}$ were, therefore, considered as stable ones when judged on the basis of this index (Table 3). In the present research, there was a highly positive and significant correlation between $\mathrm{P}_{\mathrm{i}}$ and mean yield (Table 5), revealing that the $\mathrm{P}_{\mathrm{i}}$ parameter could be helpful to identify stable genotypes having high yields. NP (i) ${ }^{1}$, $\mathrm{NP}(\mathrm{i})^{2}$, and NP $(\mathrm{i})^{3}$ were highly correlated, indicating that these four parameters could be used interchangeably in the GE interaction study of safflower. Genotypes with fewer changes in ranks are also considered to be more stable (Becker \& Leon, 1988). In non-parametric methods, $\mathrm{Si}^{(1)}$ estimates are based on all the possible pairwise rank differences across environments for each genotype, whereas $\mathrm{Si}^{(2)}$ ones are based on variances of ranks for each genotype across environments (Nassar \& Huehn, 1987). The two statistics of $\mathrm{Si}^{(1)}$ and $\mathrm{Si}^{(2)}$ showed only slight similarities in ranking the genotypes (Table 4). Some stability statistics including $\mathrm{Si}^{(1)}, \mathrm{Si}^{(2)}$, and $\mathrm{NPi}^{(1)}$ indicate the static concepts of stability; so, they cannot be correlated with mean yield (Huehn, 1996). This find- 
ing agrees well with those reported in Mohebodini et al. (2006). The positive and significant correlation between $\mathrm{P}_{\mathrm{i}}$ and SY (Table 5) demonstrated that lower values of $\mathrm{Pi}$ could be used for selection of high yield genotypes in safflower, as also reported for lentils (Mohebodini et al., 2006). While different stability statistics indicate a considerable, average, or minimal stability performance, the stability values have been found not to yield direct information contributing to making firm conclusions (Mohebodini et al., 2006). This is the reason why both parametric and non-parametric methods have been simultaneously used to analyze yield stability in different plant species such as durum wheat (Mohammadi et al., 2007), tallfescue (Dehghani et al,. 2016), lentil (Sabaghnia et al., 2006), barley (Khalili and Pour-Aboughadareh, 2016), and Cicer arietinum L. (Farshadfar et al., 2012). In the AMMI method used for safflower (Ebrahimi et al., 2016) and the parametric methods developed (Omidi Tabrizi, 2006; Pourdad \& Mohammadi, 2008), use has been made of seed yield stability analysis. Also, oil yield stability has been evaluated in safflower genotypes across different geographical regions (Ebrahimi et al., 2016). However, simultaneous analyses of these two has not yet been reported. Given the importance of proper sowing date under drought stress conditions, the present study was conducted to show how early sowing dates (15 April) could lead to the highest yield stability under nondrought conditions.

\section{CONCLUSION}

The present study showed that useful exploitation of GE interaction effects toward more precise genotype selection with respect to yield, and performance stability. Based on the results obtained in this study, $\mathrm{G}_{6}$ as a stable genotype recording an average seed yield may be recommended for regions where growing conditions are unfavorable or undergo high fluctuations. The AMMII biplot and parametric measures indicated that, based on a dynamic definition of stability, $G_{9}$ (from Mexico) followed by $G_{4}$ (from Iran) are favorable selections for yield. The results obtained from six non-parametric measures identified $\mathrm{G}_{12}$ followed by $\mathrm{G}_{2}$ as the most stable genotypes. Hence, these genotypes can be used for improved safflower adaptation to the environments under study. Finally, based on a static concept of stability, the genotype $G_{10}$ was recognized as the superior one offering a good combination of yield and stability for cultivation in both drought and non-drought environments. It is, therefore, suggested that both seed yield and stability methods should be exploited simultaneously to define the useful effects of GE interaction for selecting the best safflower genotypic selection. Further studies are, however, required to evaluate seed yield stability with different seed densities and in different geographical regions with diverse climates.

\section{ACKNOWLEDGMENTS}

The authors would like to thank Research Institute for Biotechnology and Bioengineering, Isfahan University of Technology, Isfahan, Iran.

\section{REFERENCES}

Abdulahi, A., Pourdad, S.S. \& Mohammadi, R. (2009). Stability analysis of seed yield in safflower genotypes in Iran. Acta Agronomica Hungarica, 57(2), 185-195. https://doi. org/10.1556/AAgr.57.2009.2.10

Annicchiarico, P. (2002). Defining adaptation strategies and yield-stability targets in breeding programmes. In: Kang MS (ed) Quantitative genetics, genomics, and plant breeding. CABI, Wallingford, pp. 365-383. https://doi. org/10.1079/9780851996011.0365

Becker, H.C. \& Leon, J. (1988). Stability analysis in plant breeding. Plant Breeding, 101, 1-23. https://doi. org/10.1111/j.1439-0523.1988.tb00261.x

Caliskan, S. \& Caliskan, M.E. (2018). Row and plant spacing effects on the yield and yield components of safflower in a mediterranean-type environment. Turkish Journal of Field Crops, 23(2), 85-92. https://doi.org/10.17557/tjfc.467442

Clarke, T.C., Parkin, G.W. \& Ferre, T.P.A. (2008). Soil water content. In: Carter MR, Gregorich EG (eds) Soil sampling and methods of analysis. CRC Press, Boca Raton, FL: Canadian Society of Soil Science, pp. 939-961.

Dajue, L.\& Mundel, H.H. (1996). Safflower (Carthamus tinctorius L.) Promoting the Conservation and Use of Underutilized and Neglected Crops 7. Gatersleben; Rome: Institute of Plant Genetics and Crop Plant Research; International Plant Genetic Resources Institute.

Dehghani, M.R., Majidi, M.M., Mirlohi, A. \& Saeidi, G.H. (2016). Integrating parametric and non-parametric measures to investigate genotypex environment interactions in tall fescue. Euphytica, 208(3), 583-596. https://doi. org/10.1007/s10681-015-1611-0

Ebdon, J.S. \& Gauch, H.G.Jr. (2002). Additive main effect and multiplicative interaction analysis of national turfgrass performance trials: I. Interpretation of genotype $\times$ environment interaction. Crop Science, 42, 489- 496. https://doi. org/10.2135/cropsci2002.4890

Eberhart, S.A.T. \& Russell, W.A. (1966). Stability parameters for comparing varieties. Crop Science, 6, 36-40. https://doi. org/10.2135/cropsci1966.0011183X000600010011x

Ebrahimi, F., Majidi, M.M., Arzani, A. \& Mohammadi-Nejad, G. (2016). Oil and seed yield stability in a worldwide collection of safflower under arid environments of Iran. Euphytica, 212(1), 131-144. https://doi.org/10.1007/s10681-016-1779-y 
Farshadfar, E., Sabaghpour, S.H. \& Zali, H, (2012). Comparison of parametric and non-parametric stability statistics for selecting stable chickpea (Cicer arietinum L.) genotypes under diverse environments. Australian Journal of Crop Science, 6(3), 514.

Farooq, M., Hussain, M., Wahid, A. \& Siddique, K.H.M. (2012). Drought stress in plants: an overview. In: Plant responses to drought stress (pp. 1-33). Springer, Berlin, Heidelberg. https:// doi.org/10.1007/978-3-642-32653-0_1

Francis, T.R. \& Kannenberg, L.W. (1978). Yield stability studied in short-season maize. I. A descriptive method for grouping genotypes. Canadian Journal of Plant Sciences, 58, 1029-1034. https:// doi.org/10.4141/cjps78-157

Gauch, H.G. \& Zobel, R.W. (1996). AMMI analyses of yield trials. In: Genotype by Environment Interaction. Kang M. S. and Gauch H. G. (eds.). CRC. Boca Raton, Florida, pp. 85-122. https://doi. org/10.1201/9781420049374.ch4

Gauch, H.G (2006). Statistical analysis of yield trials by AMMI and GGE. Crop Science, 46, 1488-1500. https://doi.org/10.2135/ cropsci2005.07-0193

Golkar, P. (2014). Breeding improvements in safflower (Carthamus tinctorius L.): A review. Australian Journal of Crop Science, 8(7), 1079-1085.

Huehn, M. (1996). Nonparametric analysis of genotype $x$ environment interactions by ranks. Genotype by Environ Interact CRC Press, Boca Raton, FL, pp 213-228. https://doi. org/10.1201/9781420049374.ch9

Hussain, M.I., Lyra, D.A., Farooq, M., Nikoloudakis \& N., Khalid, N. (2016). Salt and drought stresses in safflower: a review. Agronomy for Sustainable Development, 36(1), 4. https://doi. org/10.1007/s13593-015-0344-8

Moghaddam, M.J. \& Pourdad, S.S. (2009). Comparison of parametric and non-parametric methods for analysing genotypex environment interactions in safflower (Carthamus tinctorius L.). Journal of Agricultural Sciences, 147(5), 601-612. https://doi. org/10.1017/S0021859609990050

Kar, G., Kumar, A., Martha, M. (2007). Water use efficiency and crop coefficients of dry season oilseed crops. Agricultural Water Management, 87(1), 73-82. https://doi.org/10.1016/j.agwat.2006.06.002

Khalili, M. \& Pour-Aboughadareh, A. (2016). Parametric and nonparametric measures for evaluating yield stability and adaptability in barley doubled haploid lines. Journal of Agricultural Science and Technology, 18, 789-803.

Knowles, P.F. (1969). Centers of plant diversity and conservation of crop germplasm: safflower. Economic Botany, 23, 324-329. https://doi.org/10.1007/BF02860678

Kruskal, W.H. \& Wallis, W.A. (1952). Use of ranks in one-criterion variance analysis. Journal of American Statistical Association, 47(260), 583-621. https://doi.org/10.1080/01621459.1952.1048 3441

Kumar, S., Ambreen, H., Variath, M.T., Rao, A.R., Agarwal, M., Kumar, ..., Jagannath, A. (2016). Utilization of molecular, phenotypic, and geographical diversity to develop compact composite core collection in the oilseed crop, safflower (Carthamus tinctorius L.) through maximization strategy. Frontiers in Plant Science, 7, 1554. https://doi.org/10.3389/fpls.2016.01554

Lin, C.S. \& Binns, M.R. (1988). A method of analyzing cultivar $\times$ location $\times$ year experiments: A new stability parameter. Theoreti- cal and Applied Genetics, 76, 425-430. https://doi.org/10.1007/ BF00265344

Mohammadi, R., Abdulahi, A., Haghparast, R., Armion, M. (2007). Interpreting genotypex environment interactions for durum wheat grain yields using nonparametric methods. Euphytica, 157(1-2), 239-251. https://doi.org/10.1007/s10681-007-9417-3

Mohebodini, M., Dehghani \& H. Sabaghpour, S.H. (2006). Stability of performance in lentil (Lens culinaris Medik) genotypes in Iran. Euphytica, 149(3), 343-352. https://doi.org/10.1007/ s10681-006-9086-7

Nassar, R. \& Huehn, M. (1987). Studies on estimation of phenotypic stability: Tests of significance for nonparametric measures of phenotypic stability. Biometrics, 43, 45-53. https://doi. org/10.2307/2531947

Omidi Tabrizi, A.H. (2006). Stability and adaptability estimates of some safflower cultivars and lines in different environmental conditions. Agriculture and Science Technology, 8,141-151.

Pacheco, A., Vargas, M., Alvarado, G., Rodriguez, F., Crossa, J. \& Burgueno, J. (2015). "GEA-R (Genotype x Environment Analysis with R for Windows) Version 4.1”, hdl: 11529/10203, CIMMYT Research Data \& Software Repository Network, V16.

Perkins, J.M. \& Jinks, J.L. (1968). Environmental and genotype environmental components of variability. Heredity, 23, 523- 535. https://doi.org/10.1038/hdy.1968.71

Pinthus, J.M. (1973). Estimate of genotype value: A proposed method. Euphytica, 22, 21-123. https://doi.org/10.1007/BF00021563

Pourdad S.S. \& Mohammadi, R. (2008). Use of stability parameters for comparing safflower genotypes in multi environment trials. Asian Journal of Plant Science, 7(1), 100-104. https://doi. org/10.3923/ajps.2008.100.104

Purchase, J.L., Hatting, H. \& Van Deventer, C.S. (2000). Genotype $\times$ environment interaction of winter wheat in South Africa: II. stability analysis of yield performance. South African Journal of Plant and Soil, 17(3), 101-107. https://doi.org/10.1080/0257186 2.2000.10634878

Sabaghnia, N., Dehghani, H. \& Sabaghpour, S.H. (2006). Nonparametric methods for interpreting genotype 9 environment interaction of lentil genotypes. Crop Science, 46, 1100-1106. https:// doi.org/10.2135/cropsci2005.06-0122

Sayyah, S.S., Ghobadi, M., Mansoorifar, S. \& Zebarjadi, A.R. (2015). The yield of wheat genotypes associated with yield components under irrigated and drought stress after anthesis. Archives of Agronomy and Soil Science, 61(12), 1743-1755. https://doi.org/ 10.1080/03650340.2014.1001751

Shukla, G.K. (1972). Some statistical aspects of partitioning genotype-environmental components of variability. Heredity, 29, 237-245. https://doi.org/10.1038/hdy.1972.87

Steel, R.G.D. \& Torrie, J.H. (1980). Principles and procedures of statistics, a Biometrical Approach. 2nd edition. McGraw-Hill, New York, $633 \mathrm{pp}$.

Thennarasu, K. (1995). On certain non-parametric procedures for studying genotype-environment interactions and yield stability. Ph.D. Thesis. P. J. School, IARI, New Delhi.

Wricke, G. (1962). Uber eine Methode zur Erfassung der okologischen Streubreite in Feldversuchen. Zeitschrift Fur Pflanzenzuchtung-J. Plant Breeding, 47, 92-96. 